\title{
SHEAR BEAHAVIOR OF HIGH STRENGTH REINFORCED CONCRETE DEEP BEAMS
}

\author{
M. H. Ahmed, Y. A. Hassanean, A. A. Elsayed, \\ and A. M. Eldeep \\ Civil Engineering Department, Faculty of Engineering, Assuit University, \\ Assuit, Egypt
}

(Received April 21, 2009 Accepted May 4, 2009)

\begin{abstract}
Behavior of deep beams is different than that of ordinary beams. In addition the effectiveness of the biaxial state of stresses is more pronounced in deep beams. So, sixteen reinforced concrete deep beams with compressive strengths from 250 to $650 \mathrm{~kg} / \mathrm{cm}^{2}$ were tested to study their shear behavior under two-point static loading. The tested beams have shear span to depth ratio a/d from 0.5 to 1.25. All beams was singly reinforced with ratio $\rho$ from 0.0113 to 0.0254 , vertical reinforcement ratio $\rho_{v}$ from 0.1 to 0.31 , and horizontal reinforcement ratio $\rho_{h}$ from 0.19 to 0.56 .
\end{abstract}

The patterns of cracks were traced, the modes of failure were observed, and the deformations were recorded as well as both cracking and ultimate loads were also measured. Test results indicate that both the concrete compressive strength and shear span to depth ratio have a pronounced effect on the cracking and ultimate load of high strength concrete. The values of the cracking shear strength of the tested beams show a remarkable difference in comparison with the corresponding recommended values given in ACI Code equation (11-29).

KEYWORDS: High strength concrete, Shear span to depth ratio, Longitudinal steel ratio, Web reinforcement ratio.

\section{INTRODUCTION}

Reinforced concrete deep beams are used as load-destributing structural elements such as transfer girders, pile caps, and foundation walls. According to span-depth ratio, the strength of deep beams is usually controlled by shear rather than flexure if normal amounts of longitudinal reinforcement are used. In addition, shear strength of deep beams is significantly greater than predicted values using equations developed for the selender beams because of their special capacity that redistributes internal forces befor failure and developing mechanisms of force transfer quite differently from slender beams. A number of parameters affecting shear behavior have led to a limited understanding of shear failure mechanisms and predicting of exact shear strength of deep beams. These parameters include concrete compressive strength $f_{c}$, shear span to depth ratio $a / d$, amount of reinforcement, arrangement of tensile, compressive, and shear reinforcement $\rho, \rho_{\mathrm{v}}, \rho_{h}$, respectively, as well as the shape of beam, loading and support conditions. 
Among these parameters, the effects of $a / d$, and $\rho_{\mathrm{v}}, \rho_{h}$ were considered and tested as important variables in the previous investigations. Currently, with increasing the use of high-strength concrete on modern construction, additional information on the behavior of deep beams made of high-strength concrete is needed for a better understanding of the effect of $f_{c}, a / d$, and others.

In ACI Building Code [1], shear contribution of concrete $\mathrm{V}_{\mathrm{c}}$ in beams with a/d higher than 2.5 is given by ACI Eq. (11-5). ACI Eq. (11-29), the design equation for deep beams, is the equation multiplying term $3.5-2.5\left(\mathrm{M}_{\mathrm{u}} / \mathrm{V}_{\mathrm{u}} \cdot \mathrm{d}\right)$ to account for the increase of shear strength due to arching action in beams with an $a / d$ less than 2.5 . ACI Eq. (11-5) is based on the testing results of beams with compressive strengths range of 14 to $40 \mathrm{Mpa}$ (140 to $400 \mathrm{~kg} / \mathrm{cm}^{2}$ ). As a result, ACI Eq. (11-29) seems to be based on test results of beams with relatively lower compressive strengths.

Previous works [2] and [3], studied the effect of $f_{c}$ on the shear strength of beams restricted to tests of the slender or short beams. Test results of experimentaly investigation [6], showed much greater variation on the measured ultimate shear strength and evaluated the effect of concrete strength by using strength of lower bound only. Experimental investigation [8], studied the effect of $f_{c}$ on shear strength of deep beams showed compressive strength ranges from 160 to $230 \mathrm{~kg} / \mathrm{cm}^{2}$. Another previous investigation [10], for deep beams has not shown the effect of $f_{c}$ in spite of test specimens with high-strength concrete. Susanto Teng, and others [9] concluded that performance or strength of damage deep beams can be fully restored as long as their damaged failure mode is the diagonal splitting shear failure. This type of failure mode is most common for deep beams with little to moderate web reinforcements. Ramakirshman, V. [7], get that the mode of shear failure in deep beams are nearly the same as those in shallow beams under low shear span depth ratio $(a / d<2)$. The shear failure in deep beams is always initiated by splitting action, the phenomenon of failure being similar to that in a cylinder under diametral compression. Jung.K., and Sung.W.S. [4], concluded that ultimate shear strength was determined predominantly by the $a / d$, but that of deep beams was slightly affected by the le/d. ultimate shear strength of tested beams was increased slightly due to web reinforcement. In deep beams with high strength concrete, ultimate shear strength was increased slightly with addition of vertical shear reinforcement as a/d increased. Kong [5], conducted an experimented investigation using 35 simply supported deep beams, he concluded that in general, the primary cause of failure was diagonal cracking; crushing of concrete was usually only a secondary effect and failure in compression of the concrete "strut" between diagonal cracks occurred a few times only.

Effect of longitudinal steel reinforcement on shear strength is another important parameter in deep beams. An experimental investigation [2], that studied the effect of longitudinal steel reinforcement in beams with a/d less than 2.5. Test results of the investigation were compared to ACI Eq. (11-5) for short beams, without any comparison with ACI Eq. (11-29) for deep beams. As a result, there has been relatively little information on the effect of concrete strength $f_{c}$ and longitudinal steel content $\rho$ on shear strength of deep beams made of high-strength concrete.

This work was initiated to find more information about the effect of concrete compressive strength $f_{c}$, shear span to depth ratio $a / d$, longitudinal reinforcement ratio $\rho$, and web reinforcement ratio $\rho_{\mathrm{v}}, \rho_{h}$, on shear strength of deep beams with 
compressive strengths up to $650 \mathrm{~kg} / \mathrm{cm}^{2}$. Test results were compared with current design equations to assess the adequacy of ACI Eq. (11-29) for deep beams and Zsutty's equation using high strength concrete.

\section{TEST PROGRAM, MATERIALS, FABRICATION OF THE TESTED BEAMS AND TEST PROCEDURE}

\section{TEST PROGRAM}

Through testing sixteen deep beams, the shear behavior of high strength R.C deep beams under two point static loading were studied. Beam specimens were planned in five series according to studied parameters: concrete compressive strength $f_{c}$, shear span to depth ratio $a / d$, longitudinal reinforcement ratio $\rho$, vertical and horizontal reinforcement ratios $\rho_{\mathrm{v}}$ and $\rho_{h}$, respectively. Concrete compressive strength was 250 , $400,650 \mathrm{~kg} / \mathrm{cm}^{2}, a / d$ at $0.5,0.75,1.0$, and 1.25 , Longitudinal reinforcement ratio $\rho$ at $1.13,1.69$, and $2.54 \%$, Vertical shear reinforcement ratio $\rho_{\mathrm{v}}$ at $0.1,0.15,0.21$, and 0.31 $\%$, and horizontal shear reinforcement ratio $\rho_{h}$ at $0.19,0.34,0.45$, and $0.56 \%$. Figure 1 shows the details of beam specimen. All beams tested in this study have a rectangular cross section with $14 \times 70 \mathrm{~cm}$. Longitudinal steel reinforcement consisted of a straight bar with a 90 degree hook to provide adequate anchorage. Vertical shear reinforcement has closed stirrups with $6 \mathrm{~mm}$ bars, while the horizontal shear reinforcement consisted of straight $8 \mathrm{~mm}$ bars. For the restraining of local failure, in the top compressive face and support of tested beams, steel plates with widths of 18 and $13 \mathrm{~cm}$, respectively, were used.

\section{MATERIALS}

Assiut Portland cement and river fine aggregate were used to prepare the specimens. Maximum aggregate size was $16 \mathrm{~mm}$ (0.63 in.). The mixture proportion by weight per $\mathrm{m}^{3}$ is presented in Table 1. A concrete mixes were designed and cast to produce concrete of compressive strength 250,400 , and $650 \mathrm{~kg} / \mathrm{cm}^{2}$ at 28 day. Deformed bars of high tensile steel were used as tension and compression reinforcements, as well as plain bars of normal mild steel were used as a web-reinforcement.

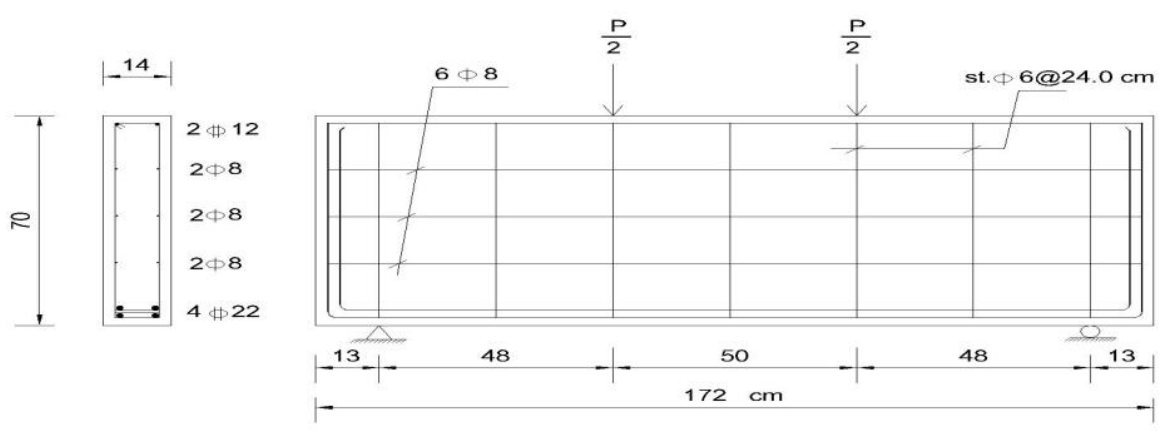

Fig. 1: Details of beams $A_{1}, A_{2}, A_{3}$ 
Table 1 : Amount of constituent materials for the different mixes.

\begin{tabular}{|c|c|c|c|c|c|c|c|c|}
\hline \multirow{3}{*}{$\begin{array}{l}\text { Mix } \\
\text { No. }\end{array}$} & \multicolumn{7}{|c|}{ Amount of constituent materials $/ \mathrm{m}^{3}$ by weight } & \multirow{3}{*}{$\mathrm{f}_{\mathrm{c}}$} \\
\hline & \multirow{2}{*}{$\begin{array}{c}\text { Cement } \\
(\mathrm{kg})\end{array}$} & \multirow{2}{*}{$\begin{array}{c}\text { Sand } \\
(\mathrm{kg})\end{array}$} & \multicolumn{2}{|c|}{$\begin{array}{c}\text { Coarse Aggr. } \\
(\mathrm{kg})\end{array}$} & \multirow{2}{*}{$\begin{array}{l}\text { Water } \\
\text { ( liter) }\end{array}$} & \multirow{2}{*}{$\begin{array}{l}\text { Silica } \\
\text { fume } \\
(\mathrm{kg})\end{array}$} & \multirow{2}{*}{$\begin{array}{l}\text { Add. } \\
(\mathrm{kg})\end{array}$} & \\
\hline & & & Gravel & Bazalt & & & & \\
\hline 1 & 350 & 618 & 1237 & - & 192.5 & - & - & 250 \\
\hline 2 & 450 & 591 & - & 1200 & 152 & 67.5 & 6.5 & 400 \\
\hline 3 & 500 & 496 & - & 1240 & 160 & 75 & 9.5 & 650 \\
\hline
\end{tabular}

Table 2 : Details of the tested beams

\begin{tabular}{|c|c|c|c|c|c|c|c|c|c|}
\hline $\begin{array}{c}\text { Series } \\
\text { No. }\end{array}$ & $\begin{array}{c}\text { Beam } \\
\text { No. }\end{array}$ & $\begin{array}{c}l \\
\mathrm{Cm}\end{array}$ & $\begin{array}{c}l_{\mathrm{b}} \\
\mathrm{Cm}\end{array}$ & $\begin{array}{c}a \\
\mathrm{Cm}\end{array}$ & $a / d$ & $\begin{array}{c}f_{\mathrm{c}} \\
\mathrm{Kg} / \mathrm{cm}^{2}\end{array}$ & $\rho$ & $\rho_{\mathrm{v}}$ & $\rho_{h}$ \\
\hline \multirow{3}{*}{$\mathrm{A}$} & $\mathrm{A} 1$ & 172 & 13 & 48 & 0.75 & 250 & 1.69 & 0.15 & 0.34 \\
& $\mathrm{~A} 2$ & 172 & 13 & 48 & 0.75 & 400 & 1.69 & 0.15 & 0.34 \\
& $\mathrm{~A} 3$ & 172 & 13 & 48 & 0.75 & 650 & 1.69 & 0.15 & 0.34 \\
\hline \multirow{3}{*}{$\mathrm{B}$} & $\mathrm{B} 1$ & 140 & 13 & 32 & 0.5 & 650 & 1.69 & 0.15 & 0.34 \\
& $\mathrm{~B} 2$ & 204 & 13 & 64 & 1.0 & 650 & 1.69 & 0.15 & 0.34 \\
& $\mathrm{~B} 3$ & 236 & 13 & 80 & 1.25 & 650 & 1.69 & 0.15 & 0.34 \\
\hline \multirow{3}{*}{$\mathrm{C}$} & $\mathrm{C} 1$ & 172 & 13 & 48 & 0.75 & 650 & 1.69 & 0.1 & 0.34 \\
& $\mathrm{C} 2$ & 172 & 13 & 48 & 0.75 & 650 & 1.69 & 0.21 & 0.34 \\
& $\mathrm{C} 3$ & 172 & 13 & 48 & 0.75 & 650 & 1.69 & 0.31 & 0.34 \\
\hline \multirow{3}{*}{$\mathrm{D}$} & $\mathrm{D} 1$ & 172 & 13 & 48 & 0.75 & 650 & 1.69 & 0.15 & 0.19 \\
& $\mathrm{D} 2$ & 172 & 13 & 48 & 0.75 & 650 & 1.69 & 0.15 & 0.45 \\
& $\mathrm{D} 3$ & 172 & 13 & 48 & 0.75 & 650 & 1.69 & 0.15 & 0.56 \\
\hline \multirow{2}{*}{$\mathrm{E}$} & $\mathrm{E} 1$ & 172 & 13 & 48 & 0.75 & 650 & 1.13 & 0.15 & 0.34 \\
& $\mathrm{E} 2$ & 172 & 13 & 48 & 0.75 & 650 & 2.54 & 0.15 & 0.34 \\
\hline \multirow{2}{*}{$\mathrm{F}$} & $\mathrm{F} 1$ & 204 & 45 & 32 & 0.5 & 650 & 1.69 & 0.15 & 0.34 \\
& $\mathrm{~F} 2$ & 236 & 61 & 32 & 0.5 & 650 & 1.69 & 0.15 & 0.34 \\
\hline
\end{tabular}

Where :

$l \quad$ Length of the beam.

$l_{\mathrm{b}} \quad$ Length of anchorage length beyond the support to the end of the beam.

a Shear span.

a/d Shear span to depth ratio.

$f_{\mathrm{c}} \quad$ Concrete compressive strength, average of 3 cubes.

$\rho \quad$ Longitudinal main steel ratio, $=\frac{A_{S}}{b \times d}$

$\rho_{\mathrm{v}} \quad$ Vertical reinforcement ratio, $=\frac{A_{s t}}{b \times l}$.

$\rho_{h} \quad$ Web reinforcement ratio, $=\frac{A_{s h}}{b \times d}$. 


\section{FABRICATION OF THE TESTED BEAMS}

The concrete was mixed mechanically and cast in steel forms. Control specimens including cube of $15 \mathrm{~cm}$ side length were cast from each mix. The beams and control specimens were sprayed with fresh water two times daily until the day before testing; all beams were tested at age of 28 days. Complete details of the tested beams are given in Table 2.

\section{TEST PROCEDURE}

Each tested beam was loaded directly with two equally concentrated loads according to the considered $a / d$. The load was applied in increments, before cracking each increment was 2.0 ton but after cracking each increment was 5.0 ton. The load was kept constant between two successive increments for about five minutes. During this period cracks were traced, the mid span deflection and strains in both main steel and concrete were recorded.

\section{ANALYSIS AND DISCUSSION OF THE TEST RESULTS}

\section{Pattern of Cracks and Mode of Failure}

All beams failed in shear, in spite of the tested beams are reinforced with different amount of reinforcement. In the early stages of loading, no flexural cracks were observed in the region of pure bending moment. With a further increase of load, diagonal cracks formed in the shear span zone and developped towards the loading points and supports.

All beams failed in diagonal tention, the inclination of the major crack making an angle between $38^{\circ}$ to $63^{\circ}$ depend on shear span to depth ratio. The inclination of the main cracks decreases by 9.0 degrees as $a / d$ ratio increases from 0.5 to 0.75 as shown in Fig. 2.

The failure modes of the tested beams are presented in Table 3. The most common failure for the tested beams is a diagonal tension failure. The failure of the beams is always initiated by splitting action, and no significant change in the failure mode was observed.

The concrete compressive strength has a considerable effect on pattern of cracks, especially for beam having higher longitudinal steel ratio. For normal strength concrete, there was a crushing of concrete under the load points. For high strength concrete, there was a vertical sliding between the two adjacent portions of the beam just to the left and right of the two load points preceded by diagonal crack. The inclination of the major crack is not effected by the concrete strength.

The number of cracks decreases as the amount of longitudinal steel ratio increases, and hence affects the inclination of the main crack in the manner that the later increased slightly as it increased as shown in Fig. 2.

The presence of web reinforcement has a considerable effect on pattern of cracks. The web reinforcement importance once already appeared at instant of the first inclined crack formation. Once the crack opens, web reinforcement works to prevent the crack widenning and propagation in the shear zones. Web reinforcement must be 
arranged to ensure that any potential diagonal tension crack encounters and does not open excessively and consequently the risk of the beam at the level of tention steel or the sudden failure without warning is prevented.

A shear failure in the tested deep beams took place through the destruction of the inclined strut that formed between the load point and the support. The failure of this strut in compression was accompanied by the shearing off of the unloaded part of the beam. The observed failure which accompanied by a vertical displacement as well as vertical sliding between the two adjacent portions of the beam just to the left and right of the two load points preceded by diagonal crack is denoted by diagonal tention failure.

Table 3 : Results of the beams tested under vertical static loading

\begin{tabular}{|c|c|c|c|c|c|c|c|c|}
\hline $\begin{array}{c}\text { Series } \\
\text { No. }\end{array}$ & $\begin{array}{c}\text { Beam } \\
\text { No. }\end{array}$ & $\begin{array}{l}\mathrm{p}_{\mathrm{cr}} \\
\text { (ton) }\end{array}$ & $\begin{array}{c}\mathrm{p}_{\mathrm{u}} \\
\text { (ton) }\end{array}$ & $\begin{array}{r}\delta_{\mathrm{cr}} \\
(\mathrm{mm})\end{array}$ & $\begin{array}{c}\delta_{\mathrm{u}} \\
(\mathrm{mm})\end{array}$ & $\begin{array}{c}\xi_{\mathrm{c}} \\
\times 10^{-5} \\
\end{array}$ & $\begin{array}{c}\xi_{\mathrm{s}} \\
\times 10^{-5} \\
\end{array}$ & $\begin{array}{c}\text { Mode Of } \\
\text { Failure }\end{array}$ \\
\hline \multirow{3}{*}{ A } & A1 & 33 & 48 & 1.62 & 2.15 & 30 & 27 & D.T. \\
\hline & $\mathrm{A} 2$ & 40 & 65 & 1.51 & 1.93 & 37 & 56 & D.T. \\
\hline & $\mathrm{A} 3$ & 45 & 85 & 1.2 & 1.67 & 48 & 67 & D.T. \\
\hline \multirow{3}{*}{ B } & B1 & 47 & 102 & 0.95 & 1.63 & 71 & 60 & D.T. \\
\hline & B2 & 43 & 80 & 1.3 & 2.1 & 51 & 75 & D.T. \\
\hline & B3 & 38 & 72 & 1.5 & 2.65 & 46 & 83 & D.T. \\
\hline \multirow{3}{*}{$\mathrm{C}$} & $\mathrm{C} 1$ & 43 & 82 & 1.07 & 1.62 & 16 & 55 & D.T. \\
\hline & $\mathrm{C} 2$ & 45 & 89 & 1.35 & 1.75 & 20 & 74 & D.T. \\
\hline & $\mathrm{C} 3$ & 47 & 92 & 1.48 & 1.8 & 35 & 79 & D.T. \\
\hline \multirow{3}{*}{$\mathrm{D}$} & D1 & 43 & 75 & 1.09 & 1.65 & 43 & 56 & D.T. \\
\hline & $\mathrm{D} 2$ & 45 & 87 & 1.33 & 1.72 & 48 & 72 & D.T. \\
\hline & D3 & 47 & 90 & 1.42 & 1.85 & 58 & 77 & D.T. \\
\hline \multirow{2}{*}{ E } & E1 & 43 & 67 & 1.6 & 2.15 & 34 & 73 & D.T. \\
\hline & E2 & 47 & 92 & 1.0 & 1.40 & 56 & 50 & D.T. \\
\hline \multirow{2}{*}{$\mathrm{F}$} & F1 & 48 & 87 & 1.4 & 2.15 & 34 & 79 & D.T. \\
\hline & $\mathrm{F} 2$ & 50 & 92 & 1.62 & 2.91 & 41 & 49 & D.T. \\
\hline
\end{tabular}

Note that the values of strains are measured at $85 \%$ of the ultimate loads.

Where:

$\mathrm{P}_{\mathrm{c}} \quad$ Initial cracking load.

$\mathrm{P}_{\mathrm{u}} \quad$ Ultimate load.

$\delta_{\text {cr }} \quad$ Deflection at cracking load.

$\delta_{\mathrm{u}} \quad$ Deflection at ultimate load.

$\xi_{\mathrm{c}} \quad$ Concrete strain.

$\xi_{\mathrm{s}} \quad$ Steel strain.

D.T. Diagonal tension failure. 


\section{$\Gamma$}

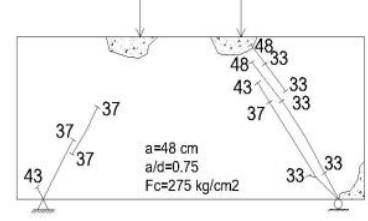

Fig. 2a: Crack pattern of beam $A_{1}$

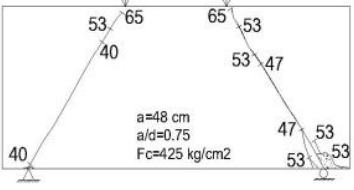

Fig. 2b: Crack pattern of beam $A_{2}$

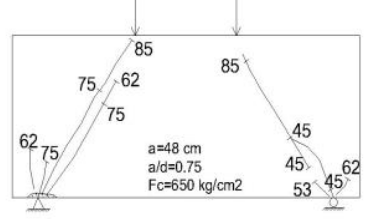

Fig. 2c : Crack pattern of beam $\mathrm{A}_{3}$

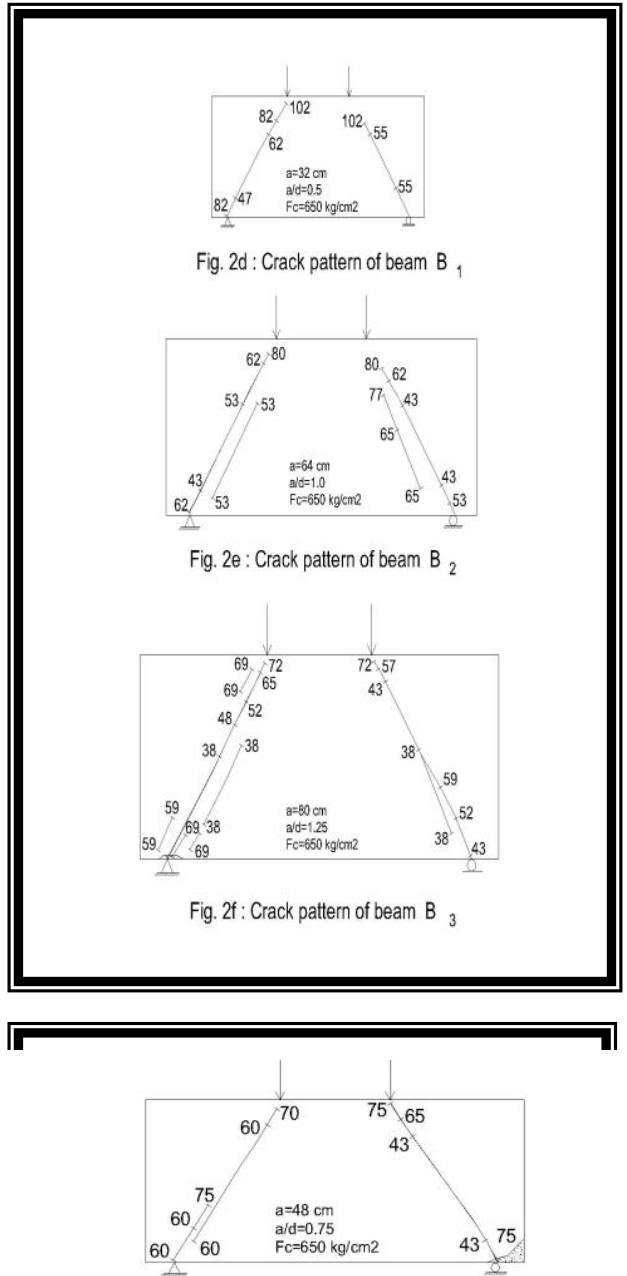

Fig. 2j : Crack pattern of beam $D_{1}$

Fig. $2 \mathrm{~g}$ : Crack pattern of beam $\mathrm{C}_{1}$

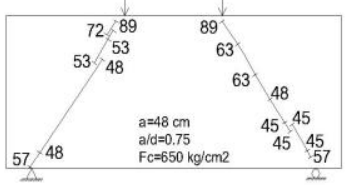

Fig. $2 \mathrm{~h}$ : Crack pattern of beam $\mathrm{C}_{2}$

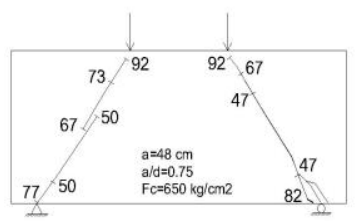

Fig. 2i : Crack pattern of beam $\mathrm{C}_{3}$

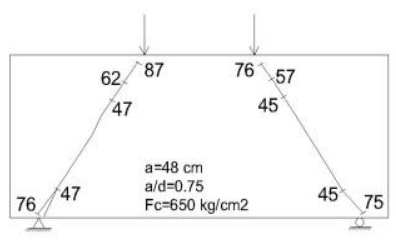

Fig. $2 k$ : Crack pattern of beam $D_{2}$

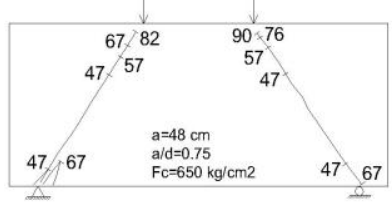

Fig. 2l : Crack pattern of beam $D_{3}$ 


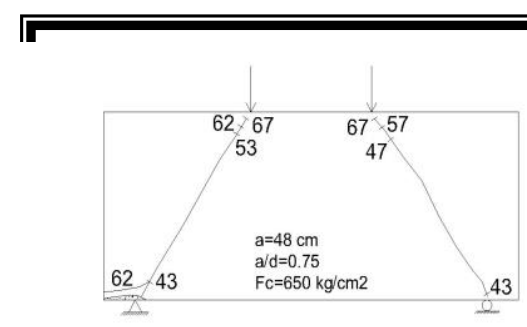

Fig. $2 m$ : Crack pattern of beam $E_{1}$

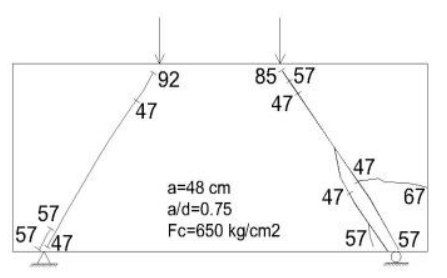

Fig. $2 n$ : Crack pattern of beam $E_{2}$

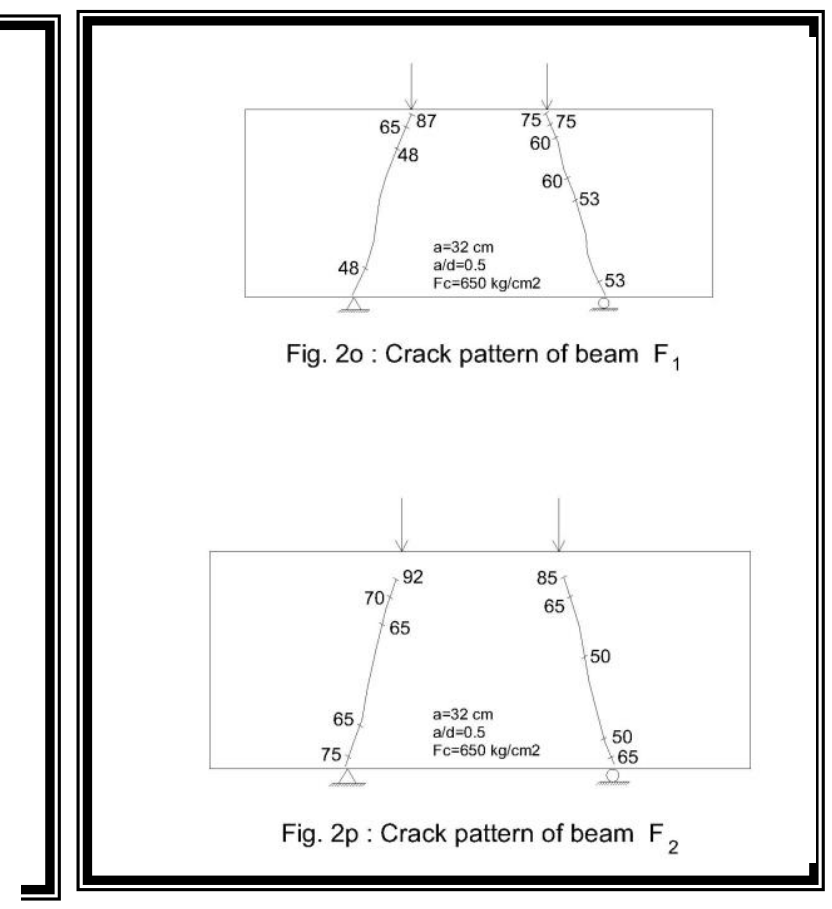

\section{Cracking and ultimate loads}

The experimental values of recorded cracking and ultimate loads for the tested beams are given in Table 3. These results indicate that, the cracking shear strength depends on the shear span to depth ratio, percentage of main steel reinforcement as well as concrete compressive strength. From investigation of Fig. 3a, it is clear that, the cracking and ultimate loads increases with the increase of concrete compressive strength. Increasing concrete compressive strength from 250 to $650 \mathrm{~kg} / \mathrm{cm}^{2}$, increasing the cracking and ultimate loads by $36.36 \%$ and $77.08 \%$ respectively, for a/d ratio of 0.75 . That indicates, the primary cause of failure was diagonal cracking; crushing of concrete was usually only a secondery effect in high strength concrete beams. The concrete compressive strength had a significant effect on the cracking and ultimate shear strength.

Also, test results show that, beams with small $a / d$ ratios have higher values of cracking and ultimate loads than that for beams having larger a/d ratios. From Fig. 3b, it appears that as shear span to depth ratio increased from 0.5 to 1.25 , the cracking and ultimate load decreased by $23.68 \%$ and $41.67 \%$ respectively, for high strength concrete. The cracking and ultimate loads are dependent on the $a / d$ ratio. This can be illustrated by the fact that the tied arching action becomes less effective with an increasing of $a / d$ ratio, because of the reduced angle between the inclined strut and longitudinal axis of the beam.

The effect of longitudinal steel ratio on the cracking and ultimate loads is shown in Fig. 3c. Increasing of longitudinal steel ratio increases the cracking and ultimate loads. Increasing longitudinal steel ratio from 0.0113 to 0.0254 increasing the cracking and ultimate load by $9.3 \%$ and $37.31 \%$ respectively. The increasing of 
cracking and ultimate loads is mainly due to the fact that the increasing of longitudinal reinforcement in the beam increase the elastic stiffness of the beam. Increasing longitudinal steel ratio usually increases both the dowel capacity of the member and the aggregate interlock capacity. Beams with low longitudinal steel ratio had wide cracks in contrast to the narrow cracks found in beams with high longitudinal steel ratio. Since the aggregate interlock mechanism depends on the crack width, an increase in the aggregate interlock force is to be expected with an increase in longitudinal steel ratio. Also, increasing longitudinal steel ratio increases the shear strength, which carried by compression zone. As the area of tension reinforcement increases, the neutral axis moves towards the steel, hence the area of compression zone increases, and then, the shear force increases.

The relationship between measured cracking and ultimate loads versus amount of vertical reinforcement ratio is shown in Fig. 3d. With an increasing ratio of vertical reinforcement, the cracking and ultimate load tends to increase slightly due to shear contribution of vertical reinforcement. Additional amount of vertical reinforcement ratio have a small effect on the ultimate load, and seems to have a relatively small effect on the strength of the tested beams.

Variation of cracking and ultimate loads versus horizontal reinforcement ratio for tested beams with constant $\rho_{v}$ is shown in Fig. 3e. The effect of horizontal reinforcement ratio on the cracking and ultimate loads in deep beams is less than the effect of vertical reinforcement ratio. As a result, it seems that shear capacity due to dowel action by horizontal reinforcement has a little effect on ultimate load of deep beams. The maximum increase in cracking and ultimate load was about $9.3 \%$ and $20 \%$, respectively as the horizontal reinforcement ratio increased from 0.0019 to 0.0056 . The increasing of cracking load is mainly due to the fact that the existing of bars in the side face of the beam delayed the appearance of cracks and increasing the elastic stiffness of the cross section. In general, this is because providing the beam with horizontal bars affected the crack pattern and helps to stop the growth of diagonal cracks and hence increasing the ultimate loads of the tested beams.

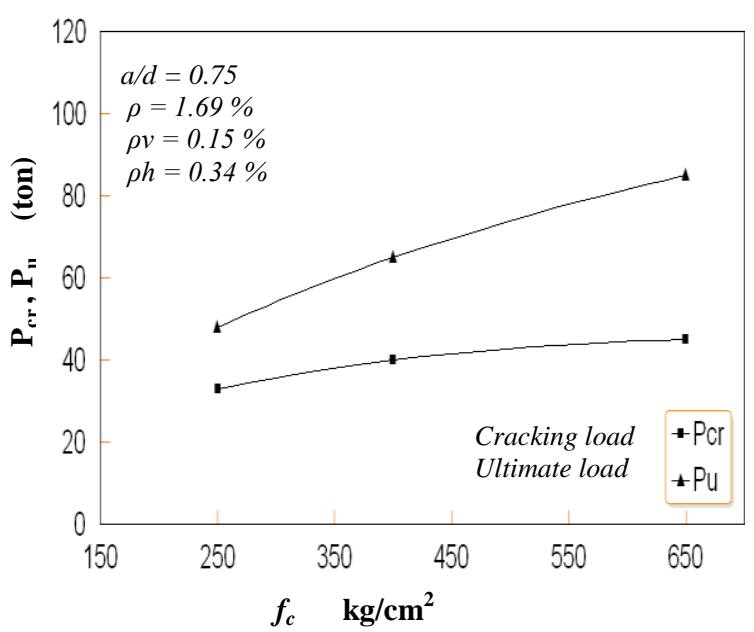

Fig. 3a : Effect of concrete strength on cracking and ultimate loads.

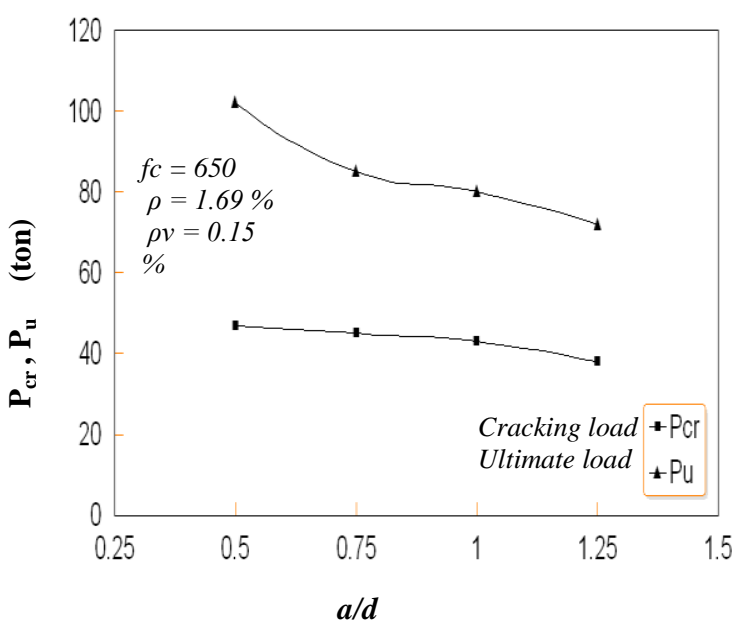

Fig. 3b : Effect of shear span to depth ratio on cracking and ultimate loads.to depth ratio. 


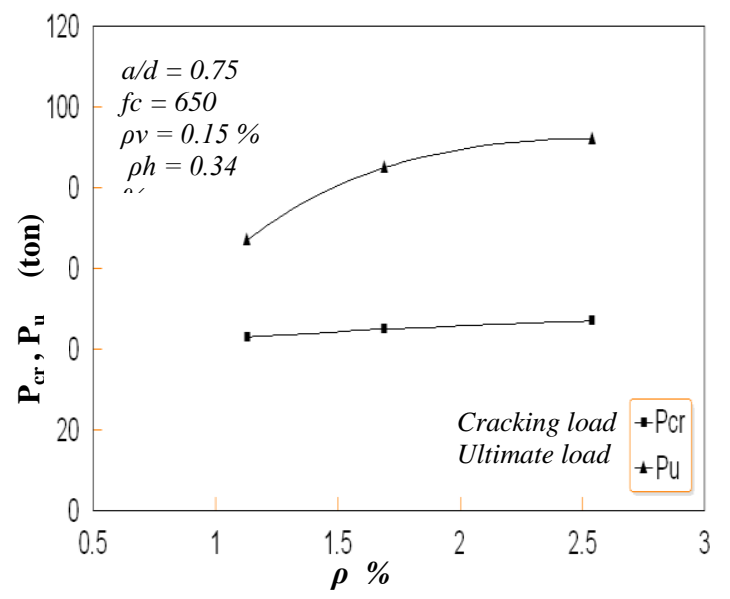

Fig. 3c : Effect of steel reinforcement ratio on cracking and ultimate loads.

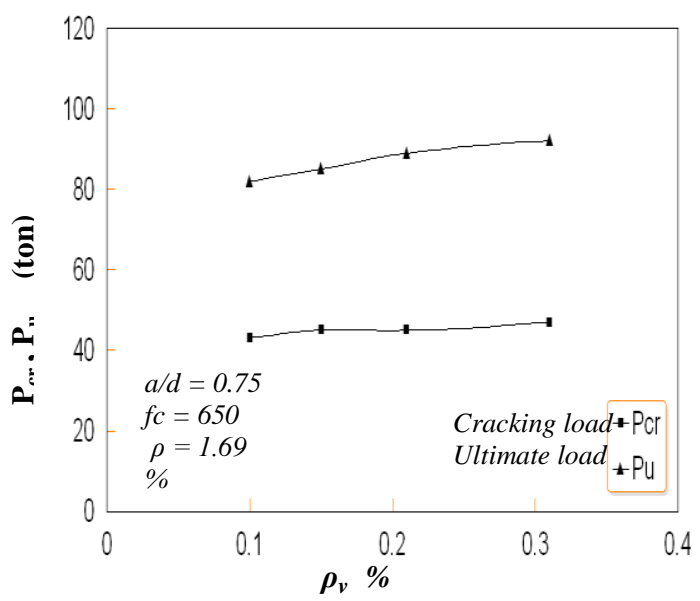

Fig. 3d : Effect of vertical reinforcement ratio on cracking and ultimate loads.

Figure 3f, indicate that bond length have a minor effect on the cracking and ultimate load. The cracking and ultimate loads are increased slightly as the bond length increases.

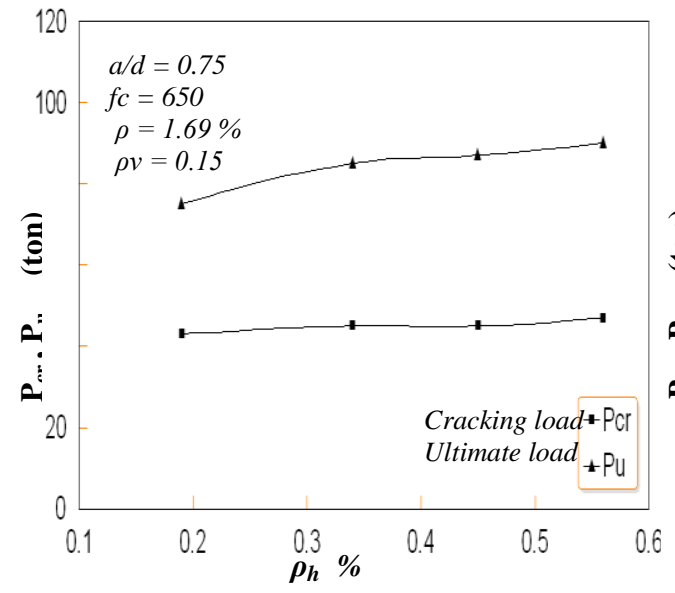

Fig. 3e : Effect of horizontal reinforcement ratio on cracking and ultimate loads.

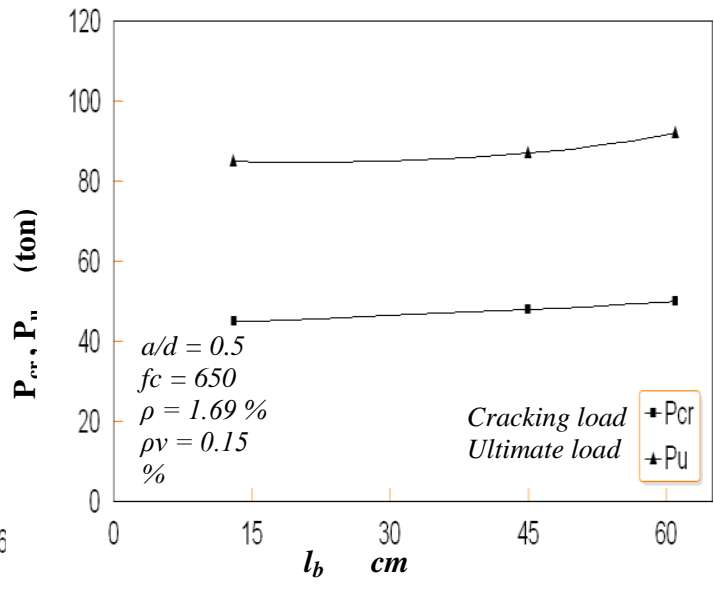

Fig. 3f : Effect of anchorage length on cracking and ultimate loads.

\section{Maximum Deflection}

Figure 4, shows the relationship between the applied load and the recorded deflection at position of maximum deflection, (mid span deflection), while in Table 3. the maximum values of deflection are presented for all tested beams. Generally the maximum deflection at different loads changed distinctly by changing concrete strength, shear span to depth ratio, longitudinal steel ratio, vertical reinforcement ratio, and bond length. 
Figure 4a, show how the cracking and ultimate deflection are influenced by concrete strength. The maximum deflection decreases as the concrete compressive strength increases. The maximum deflection was increased from $1.67 \mathrm{~mm}$ to $2.15 \mathrm{~mm}$, when the concrete compressive strength $\left(f_{\mathrm{c}}\right)$ decreased from $650 \mathrm{~kg} / \mathrm{cm}^{2}$ to $250 \mathrm{~kg} / \mathrm{cm}^{2}$. Increasing of concrete compressive strength increases the modulus of elasticity which means that the increase of stiffness of the beam decreases the corresponding maximum deflection.

The maximum deflection at any load depends mainly on the shear span to depth ratio. For constant load, the maximum deflection increases as shear span to depth ratio increases. Also, it is noticed that as a/d ratio increased from 0.5 to 1.25 , the inclination of the tangent of the curve at the origin decreases by $62.58 \%$ for high strength concrete. When the shear span to depth ratio increased, the maximum deflection increased as a result of reduction in flexural stiffness of the beam due to the increased numbed of formed cracks and their widening. See Fig. $\mathbf{4 b}$.

The maximum deflection of the tested beams decreased as the longitudinal reinforcement ratio increased. The maximum deflection decreased by $34.88 \%$, as the longitudinal reinforcement ratio increased from 0.0113 to 0.0254 . Increasing longitudinal steel ratio means increasing the stiffness of the beam. This is true since, increasing $(\rho)$, increases the neutral axis depth that caused a reduction in the strain in the tention reinforcement and consequently decrease the number, length, and width of the cracks and consequently the corresponding deflection. See Fig. 4c.

Figure 4d, indicates that, the maximum deflection increases slightly as the vertical reinforcement ratio increases. The slope of midspan deflection curves seems to be independent of the amount of vertical reinforcement. This is because the vertical reinforcement contributes in the shear rigidity of the beam and the shear deformation is very small.

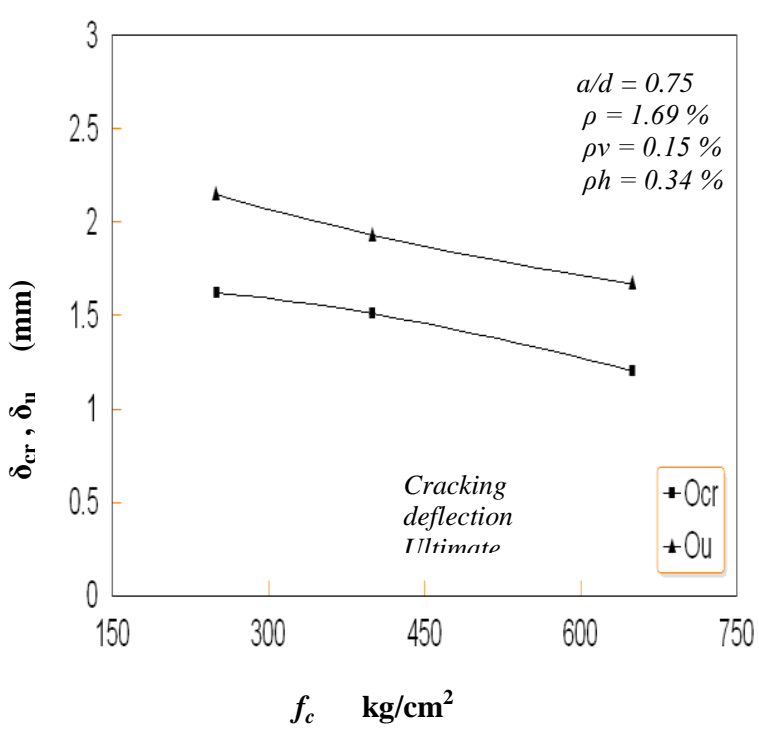

Fig. 4a : The relation between cracking and ultimate deflections with concret strength

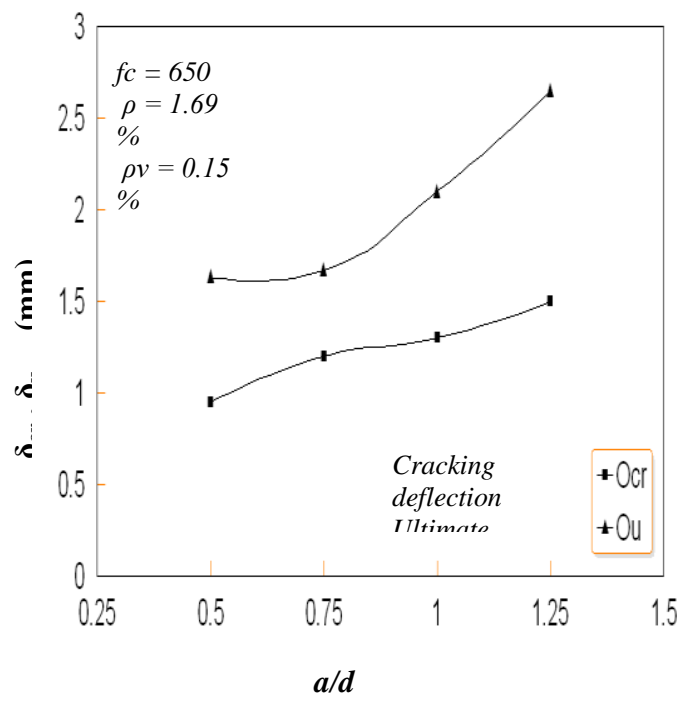

Fig. 4b : The relation between cracking and ultimate deflections with shear span to depth ratio. 


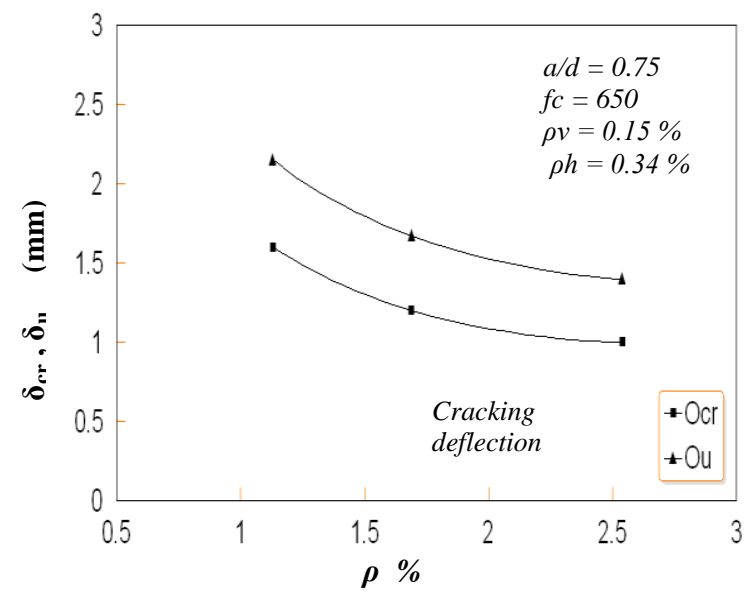

Fig. 4c : The relation between cracking and ultimate deflections with steel reinforcement ratio.

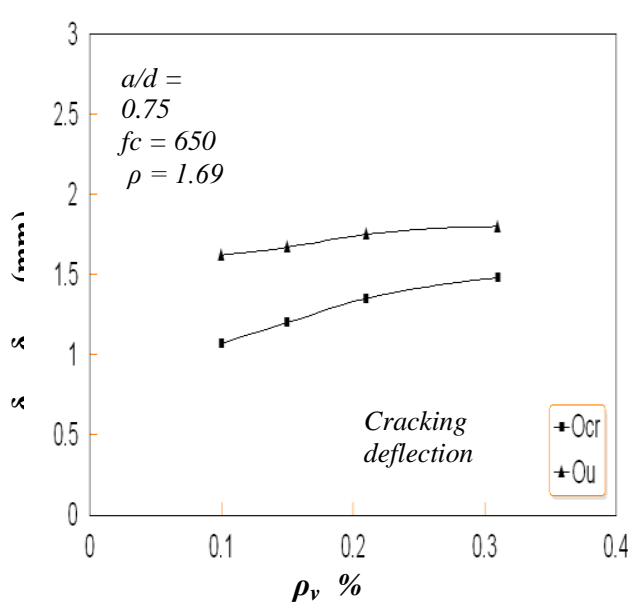

Fig. 4d : The relation between cracking and ultimate deflections with vertical reinforcement ratio.

The maximum deflection increases slightly as the horizontal reinforcement ratio increases. The slope of midspan deflection curves seems to be independent of the amount of horizontal reinforcement. When the horizontal reinforcement ratio increases, the ductility of the beam increases. Usually the crack numbers and maximum deflection increase as a result of increasing the ductility. See Fig. 4e.

The maximum deflection increases, by the increase of bond length of the beam beyond supports for $l_{\mathrm{b}}>20 \mathrm{~d}_{\mathrm{p}}$. This is because the increase of the ultimate load. See Fig. $4 f$.

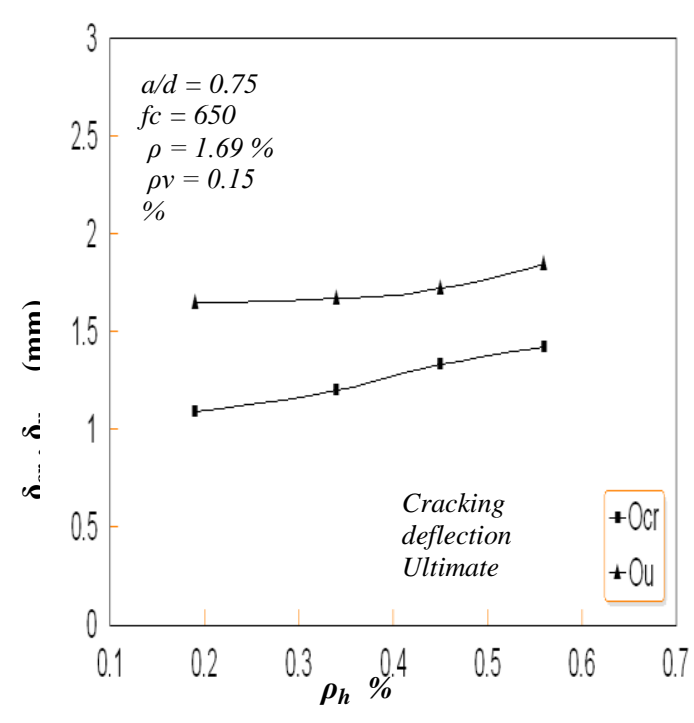

Fig. 4e : The relation between cracking and ultimate deflections with horizontal reinforcement ratio.

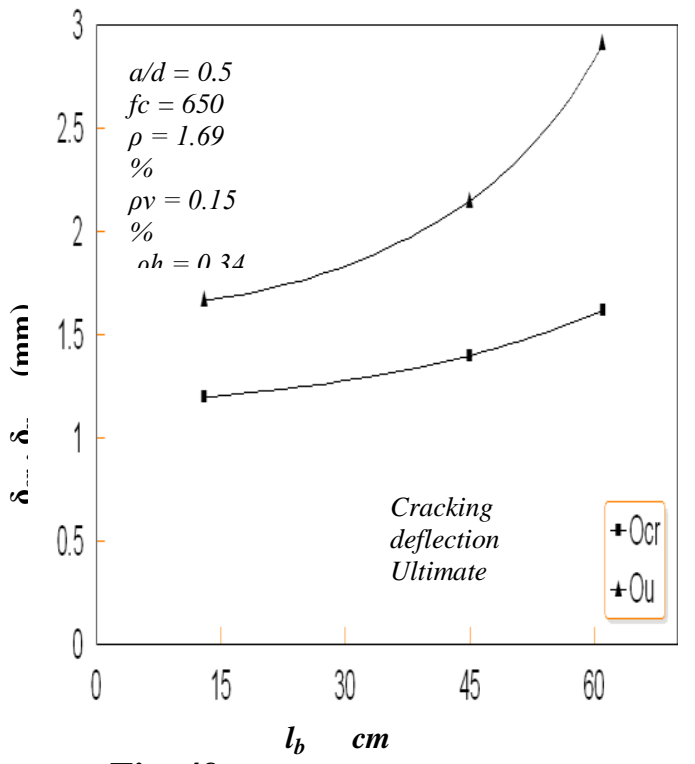

Fig. 4f : The relation between cracking and ultimate deflections with anchorage Length 


\section{Strain in both Main Steel and Concrete}

The values of strain in both main steel and concrete at extreme fibers of compression zone were measured under loading point of the tested beams and shown in Fig. 5. The values of the induced strain at load level about $85 \%$ of the ultimate load were given in Table 3.

From the relations between the applied load and induced concrete compressive strain of all tested beams, it can be noticed that, the concrete strain increases with the increasing of concrete compressive strength, longitudinal steel ratio, web reinforcement ratio and decreases with the increase of shear span to depth ratio. While no clear relation in the observed results with the change of bond length. The effects of the studied parameter are shown in Figs. 5a. to 5f.

From the relations between the applied load and induced main steel strain of all tested beams, it can be noticed that, the maximum main steel strain increases by increasing concrete strength, shear span to depth ratio, web rainforcement ratio. Meanwhile decreases by increasing of longitudinal steel ratio. The effects of the studied parameter are shown in Figs. 5a. to 5f.

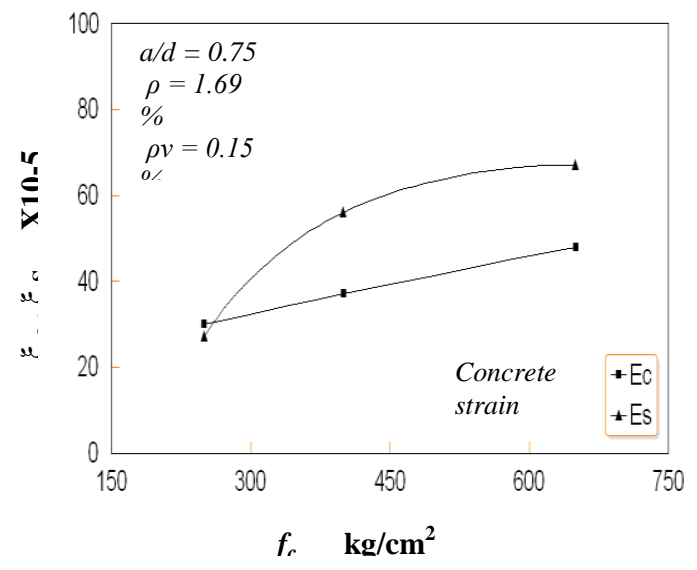

Fig. 5a : The relation between concrete and main steel strain with concret strength.

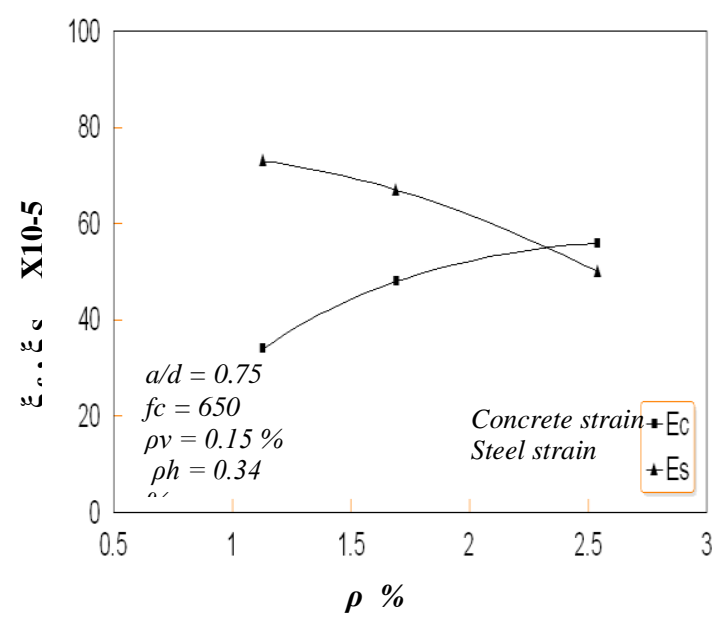

Fig. 5c : The relation between concrete and main steel strain with steel reinforcement ratio.

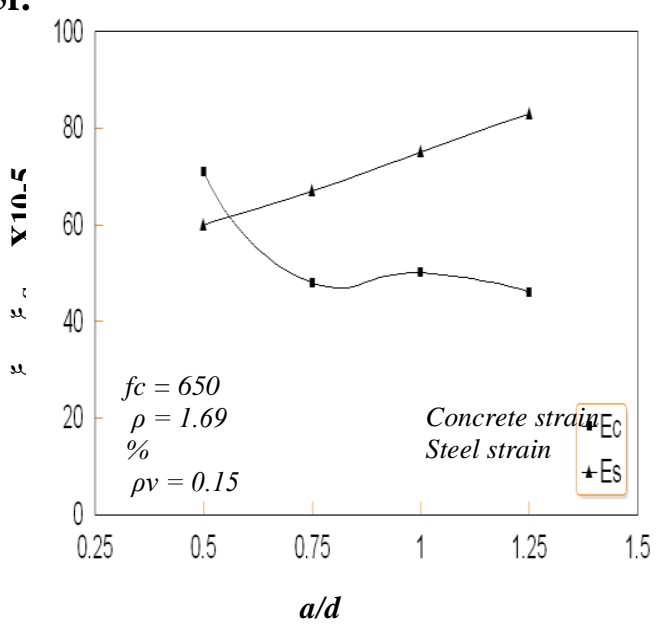

Fig. 5b : The relation between concrete and main steel strain with shear span to depth ratio.

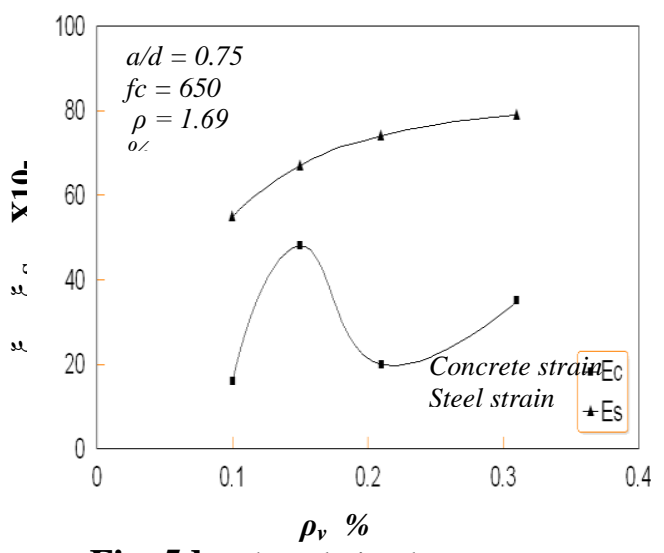

Fig. 5d : The relation between concrete and main steel strain with vertical reinforcement ratin. 


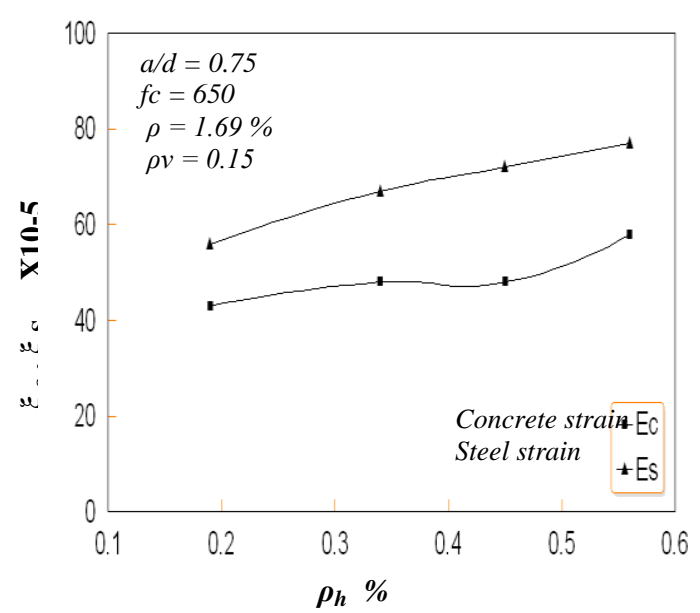

Fig. 5e : The relation between concrete and main steel strain with horizontal reinforcement

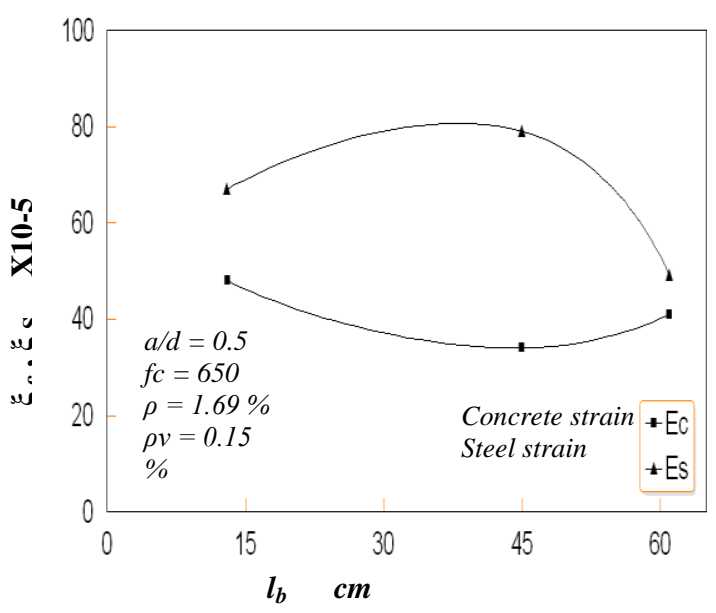

Fig. 5f : The relation between concrete and main steel strain with anchorage Length.

\section{Comparison of Shear Strength of the Tested Beams with Important Equations}

The aim of this part is to make a comparison between the obtained results and those proposed in ACI-code [1], and Zsutty, ${ }^{\text {, }}$ [11].

\section{a - American concrete institute [1]}

In the ACI Code [1], the value of $v_{\text {cr }}$ is calculated from the formula ;

$\mathrm{U}_{\mathrm{cr}}=\left(3.5-2.5 \frac{M}{V \cdot d}\right)\left(1.9 \sqrt{f_{c}^{-}}+2500 \rho \frac{V \cdot d}{M}\right)$

or $\mathrm{V}_{\mathrm{cr}}=\left(3.5-2.5 \frac{M}{V \cdot d}\right)\left(1.9 \sqrt{f_{c}^{-}}+2500 \rho_{w} \frac{d}{a}\right) \mathrm{b}_{\mathrm{w}} \mathrm{d} \quad$ ACI Eq.(11-29)

Where $\mathrm{v}_{\mathrm{cr}}$ and $f_{c}$ ' are in p.s.i.

\section{b-Zsutty equation [11]}

Zsutty derived an equation for predicting the cracking shear strength for ordinary beams. The derived equation is given below in p.s.i.

$\mathrm{v}_{\mathrm{cr}}=59\left(f_{c}^{\prime} \cdot \rho \cdot \frac{d}{a}\right)^{0.33}$

or $\quad \mathrm{V}_{\mathrm{cr}}=59\left(f_{c}^{\prime} \cdot \rho \cdot \frac{d}{a}\right)^{0.33} \mathrm{~b}_{\mathrm{w}} \mathrm{d}$

If Zsutty equation multiplied by a constant term $\left(3.5-2.5 \frac{M}{V \cdot d}\right)$ which is in the ACI Eq.(11-5) to obtain ACI Eq.(11-29) for deep beams. The derived equation will be: 
$\mathrm{V}_{\mathrm{cr}}=\left(3.5-2.5 \frac{M}{V \cdot d}\right) 59\left(f_{c}^{\cdot} \cdot \rho \cdot \frac{d}{a}\right)^{0.33} \mathrm{~b}_{\mathrm{w}} \mathrm{d}$

The values of $\left(\mathrm{P}_{\mathrm{cr}}\right)$ from test results, the predicted values by ACI. Code, and modefied Zsutty,s equation are given in Table 4. From Table 4, and Fig. 6, it appears that ACI Code equation (11-29) is conservative for most values and underestimates the importance of concrete compressive strength, longitudinal steel ratio, web reinforcement ratio, and it tends to be unconservative for high values of shear span to depth ratio. Also it can be noticed that Zsutty`s equation is conservative for most values and underestimates the importance of concrete strength, longitudinal steel ratio, web reinforcement ratio, and it tends to be unconservative for high values of shear span to depth ratio.

Comparing the test results by the predicted results, it appears that ACI Code equation (11-29) and Zsutty's equation is unconservative for $a / d$ ratio $>0.75$ for high strength concrete. While it is conservative for $0.5 \leq a / d$ ratio $<0.75$ for high strength concrete. The difference between experimental and theoretical values given by ACI Code and Zsutty ${ }^{\text {s }}$ equation may be attributed to the effect of vertical, horizontal reinforcement ratios and anchorage length $\left(\rho_{v} \%, \rho_{h} \%\right.$, and $\left.l_{b}\right)$ respectively which is not included in the theoretical equations. However, the vertical, horizontal reinforcement ratios and anchorage length has a minor effect upon the cracking load.

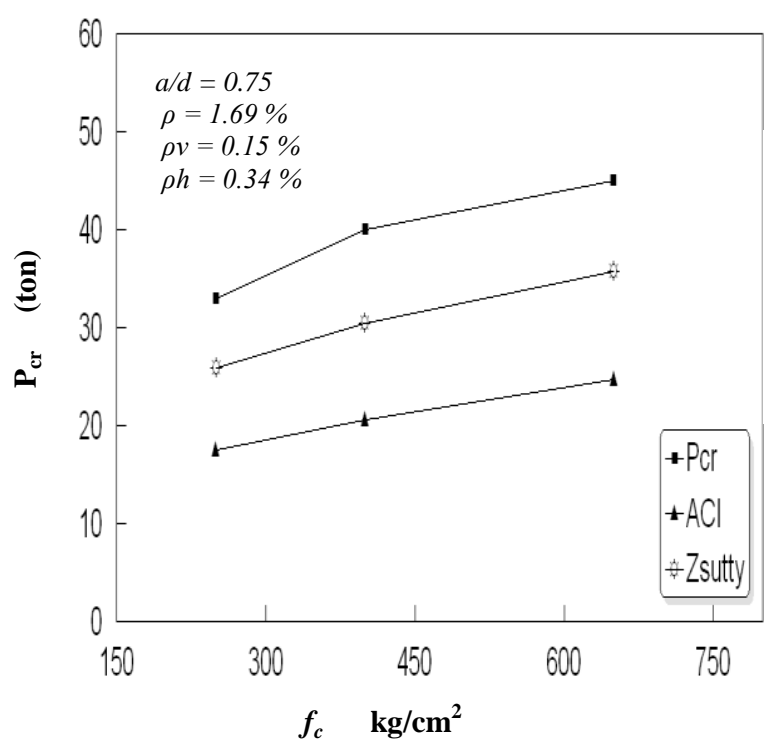

Fig. 6a : Influence of concrete streength on the cracking load.

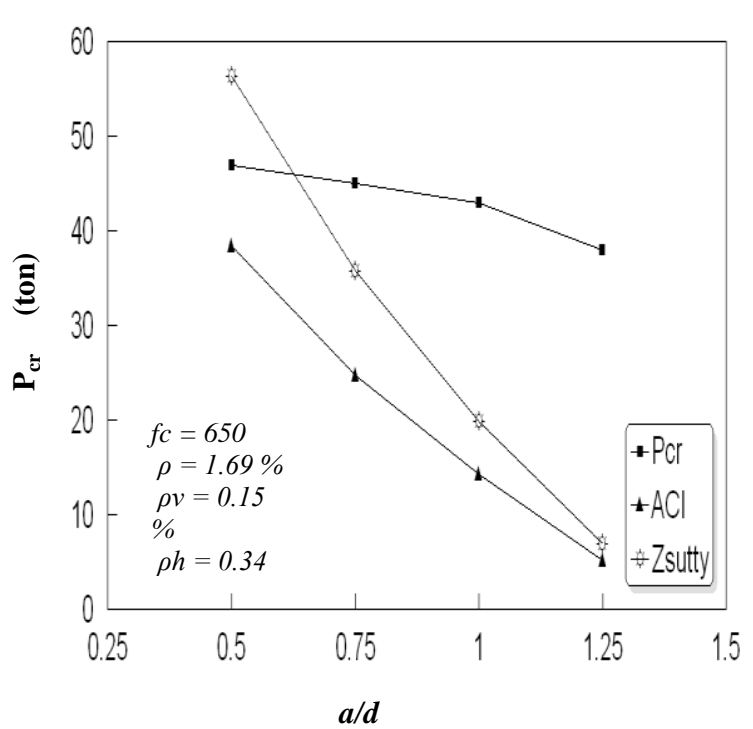

Fig. 6b : Influence of shear span to depth ratio on the cracking load. 


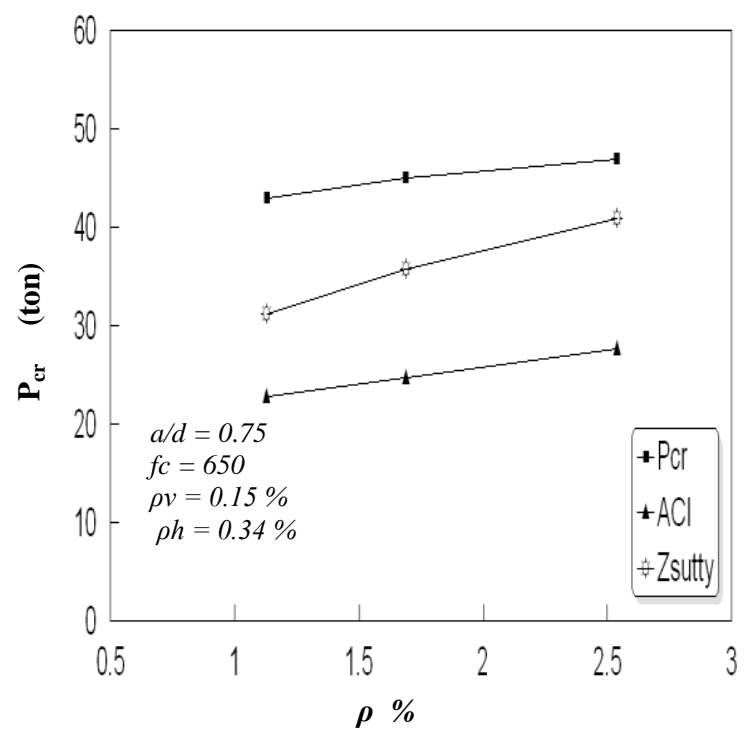

Fig. 6c : Influence of longitudinal steel ratio on the cracking load.

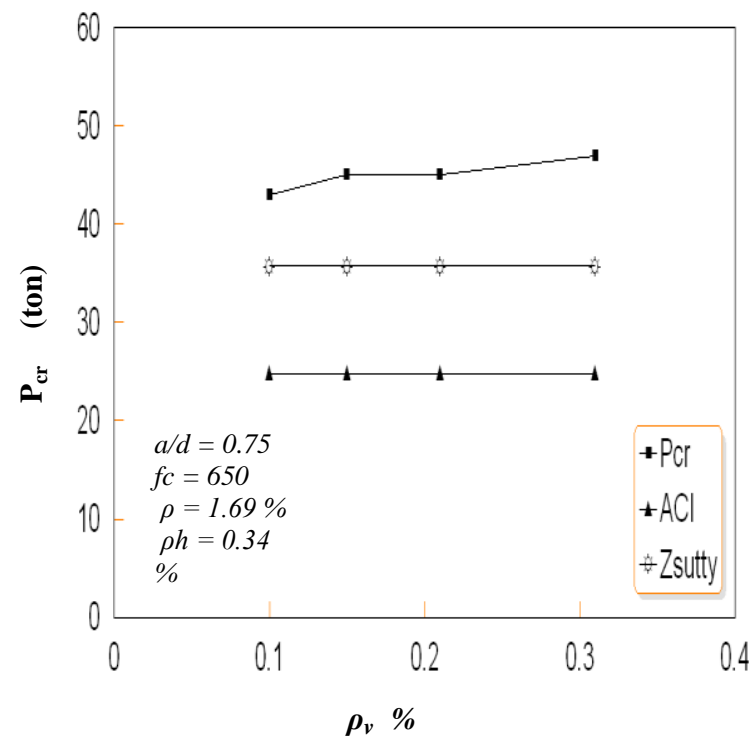

Fig. 6d : Influence of vertical reinforcement ratio on the cracking load.

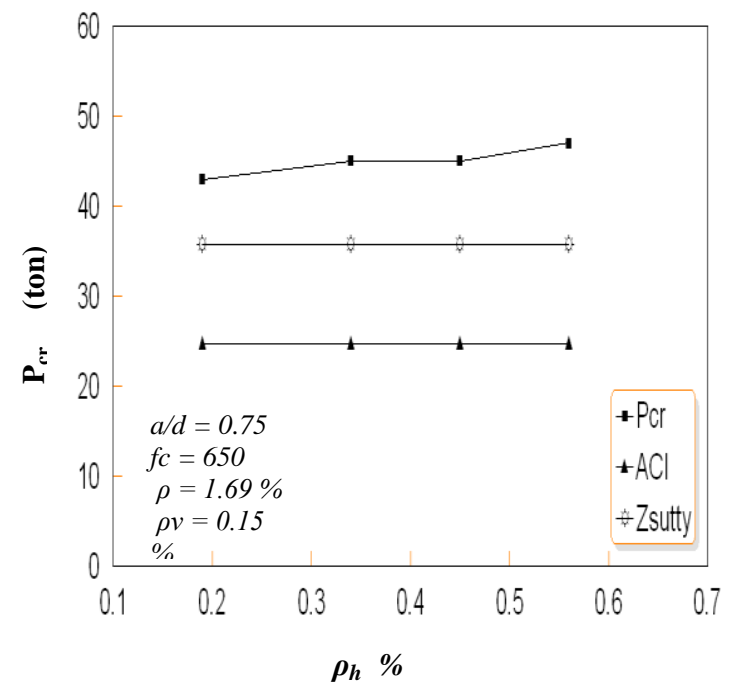

Fig. 6e : Influence of horizontal reinforcement on the cracking load.

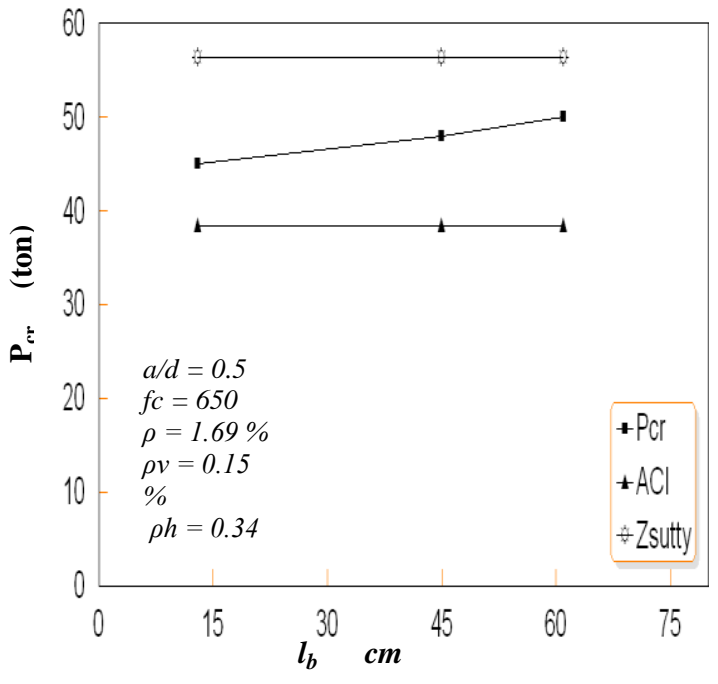

Fig. 6f : Influence of anchorage length on the cracking load. 
Table 4 : Comparison between the experimental values of $\mathrm{P}_{\mathrm{cr}}$ of the test and that expected by ACI equation and Zsutty ${ }^{\text {,s }}$ equation.

\begin{tabular}{|c|c|c|c|c|c|c|}
\hline $\begin{array}{c}\text { Series } \\
\text { No. }\end{array}$ & $\begin{array}{c}\text { Beam } \\
\text { No. }\end{array}$ & $\begin{array}{c}\mathrm{P}_{\text {cr }} \text { test } \\
\text { (ton) } \\
(1)\end{array}$ & $\begin{array}{c}\mathrm{P}_{\text {cr ACI }} \\
\text { (ton) (2) }\end{array}$ & $\begin{array}{c}\mathrm{P}_{\text {cr }} \text { Zsutty } \\
\text { (ton) (3) }\end{array}$ & $\mathrm{P}_{\text {cr }}(1) / \mathrm{P}_{\text {cr }}(2)$ & $\begin{array}{c}\mathrm{P}_{\text {cr }}(1) / \\
\mathrm{P}_{\text {cr }}(3)\end{array}$ \\
\hline \multirow{3}{*}{$\mathrm{A}$} & $\mathrm{A} 1$ & 33 & 17.58 & 25.97 & 1.88 & 1.27 \\
& $\mathrm{~A} 2$ & 40 & 20.70 & 30.42 & 1.93 & 1.31 \\
& $\mathrm{~A} 3$ & 45 & 24.80 & 35.71 & 1.81 & 1.26 \\
\hline \multirow{3}{*}{$\mathrm{B}$} & $\mathrm{B} 1$ & 47 & 38.37 & 56.39 & 1.22 & 0.83 \\
& $\mathrm{~B} 2$ & 43 & 14.37 & 19.94 & 2.99 & 2.16 \\
& $\mathrm{~B} 3$ & 38 & 5.19 & 6.95 & 7.32 & 5.47 \\
\hline \multirow{3}{*}{$\mathrm{C}$} & $\mathrm{C} 1$ & 43 & 24.80 & 35.71 & 1.73 & 1.20 \\
& $\mathrm{C} 2$ & 45 & 24.80 & 35.71 & 1.81 & 1.26 \\
& $\mathrm{C} 3$ & 47 & 24.80 & 35.71 & 1.90 & 1.32 \\
\hline \multirow{2}{*}{$\mathrm{D}$} & $\mathrm{D} 1$ & 43 & 24.80 & 35.71 & 1.73 & 1.20 \\
& $\mathrm{D} 2$ & 45 & 24.80 & 35.71 & 1.81 & 1.26 \\
& $\mathrm{D} 3$ & 47 & 24.80 & 35.71 & 1.90 & 1.32 \\
\hline \multirow{2}{*}{$\mathrm{E}$} & $\mathrm{E} 1$ & 43 & 22.88 & 31.27 & 1.88 & 1.38 \\
& $\mathrm{E} 2$ & 47 & 27.71 & 40.85 & 1.70 & 1.15 \\
\hline \multirow{2}{*}{$\mathrm{F}$} & $\mathrm{F} 1$ & 48 & 38.37 & 56.39 & 1.25 & 0.85 \\
& $\mathrm{~F} 2$ & 50 & 38.37 & 56.39 & 1.30 & 0.89 \\
\hline
\end{tabular}

\section{CONCLUSIONS}

In this study the effect of compressive strength $\left(f_{c}\right)$, shear span to depth ratio $(a / d)$, longitudinal steel ratio $(p)$, web reinforcement ratio $\left(p_{v}, p_{h}\right)$, and bond length $\left(l_{b}\right)$ on the shear strength of high strength reinforced concrete deep beams under static loading was investigated experimentally.

1- The concrete compressive strength has a pronounced effect on the cracking and ultimate load of high strength concrete. Increasing concrete compressive strength from 250 to $650 \mathrm{~kg} / \mathrm{cm}^{2}$, increasing the cracking and ultimate loads by $36.36 \%$ and $77.08 \%$ respectively, for $a / d$ ratio of 0.75 .

2- The shear span to depth ratio $(a / d)$ has a pronounced effect on the cracking and ultimate load of high strength concrete tested deep beams. The ultimate shear strength is increased significantly with a decreasing of $a / d$.

3- The longitudinal steel reinforcement have a significant effect on the diagonal cracking and ultimate loads.

4- Additional amount of vertical reinforcement ratio seems to have a relatively small effect on the strength of the tested beams, no effect of development of inclined crack.

5- Horizontal reinforcement has relatively minor effect on the cracking and ultimate loads, as well as the detailing of the main steel since mainly vertical tensile forces are required to be carried.

6- No significant change in the failure mode was observed between normal and high strength concrete deep beams. 
7- Ultimate shear strength of tested beams was increased slightly due to web reinforcement ratio. In deep beams with high strength concrete, ultimate shear strength was increased slightly with increasing of web reinforcement.

8- The maximum measured deflection decreses, with the increase of concrete compressive strength and longitudinal steel ratio. Also the maximum measured deflection increases, with the increase of shear span to depth ratio and web reinforcement ratio.

9- The higher the shear span to depth ratio, the smooth the load-deflection curve, i.e, with increasing $a / d$, the beam becomes flexible. With an increasing of $a / d$, the mid span deflection tends to decrease due to increase of moment span.

10- Horizontal reinforcement ratio has a pronounced effect in controlling deflection; widely spaced horizontal reinforcement was not effective in controlling deflection.

11- The maximum concrete strain increases, with the increase of concrete compressive strength and longitudinal steel ratio, and decreases with the increase of shear span to depth ratio. Also the maximum steel strain increases, with the increase of concrete compressive strength, shear span to depth ratio, and decreases with the increase of longitudinal steel ratio.

12- The values of the cracking load of the tested beams show a remarkable difference in comparison with the corresponding recommended values given in ACI Code equation (11-29).

13- The predicted values of $\mathrm{V}_{\mathrm{cr}}$ by modified Zsutty's equation slightly agree with that achieved from the tests. If Zsutty ${ }^{\text {s }}$ equation multiplied by a constant term of (3.5 $-2.5 \frac{M}{V \cdot d}$ ), it can better predict the trend, for $0.5 \leq a / d$ ratio $<0.75$ for high strength concrete.

\section{REFERENCE}

[1] ACI Committee 318, "Building Code Requirements for Reinforced Concrete (318-99)," American Concrete Institute, Farmington Hills, Mich., 1999, 391 pp.

[2] Ahmad, S. H.; Khaloo, A. R.; and Poveda, A., "Shear Capacity of Reinforced High-Strength Concrete Beams," ACI Journal, Proceedings V.83, No. 2, Mar.Apr. 1986, pp. 297-305.

[3] Elzanaty, A. H.; and Slate, F. O ., "Shear Capacity of Reinforced Concrete Beams Using High-Strength Concrete," ACI Journal, Proceedings V.83, No. 2, Mar.Apr. 1986, pp. 290-296.

[4] Jung-Keun Oh, and Sung-Woo Shin, "Shear Strength of Reinforced high Strenegth Concrete Deep Beams," ACI Structural Journal, March-April 2001, p.p. 164-173.

[5] kong, F.K., Robins, P.J., "Web Reinforcement Effects on Deep Beams," ACI Journal, Dec., 1970, p.p. 1010-1070.

[6] Mphonde,A. G., and Frantz, G. C., "Shear Tests of High-and Low-Strength Concrete beams without Stirrups," ACI Journal, Proceedings V.81, No. 4, JulyAug. 1984, pp. 191-198.

[7] Ramakrishnan, V., and Ananthanarayana, Y., "Ultimate Stength of Deep Beams in Shear," ACI Journal, Title No. 65-7, February 1968, pp. 87-98. 
[8] Smith, K. N., and Vantsiotis, A. S., "Shear Strength of Deep Beams," ACI Journal, Proceedings V.79, No. 3, May-June 1982, pp. 201-213.

[9] Susanto Teng, Fung-Kew Kong, Soon Poh, Lingwei W. Guan, and Kang-Hai Tan, "Performance of Strengthened Concrete Deep Beams Predamaged in Shear," ACI Structural Journal/March-April 1996, p.p. 159-170.

[10] Tan, K.-H.; Kong, F.-K.; and Guan, L., "High-Strength Concrete Deep Beams with Effictive Span and Shear Span Variations," ACI Structural Journal, V.92, No. 4, July-Aug. 1995, pp. 395-405.

[11] Zsutty, T., "Shear Strength Prediction for Separate Categories of Simple Beam Tests," ACI Journal, Vol. 68, No. 2, February, 1971.

\section{سلوك القص للكمرات الخرسانية المسلحة العميقة عالية المقاومة}

من المعروف أن المنشآت الخرسانية المعرضة لإجهادات عالية كما هو الحال فى المنشآت المقامة أسفل

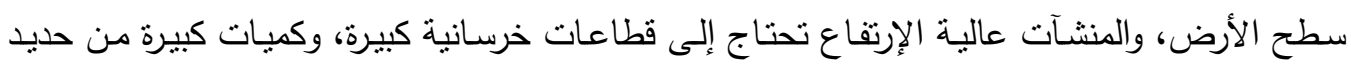

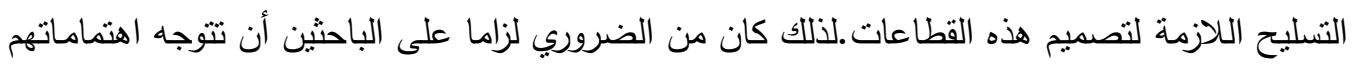

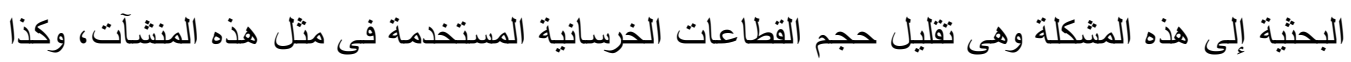

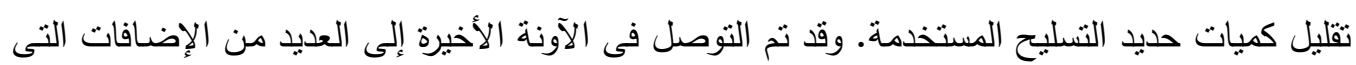

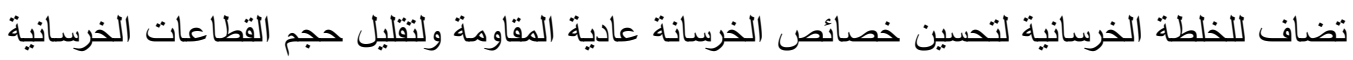

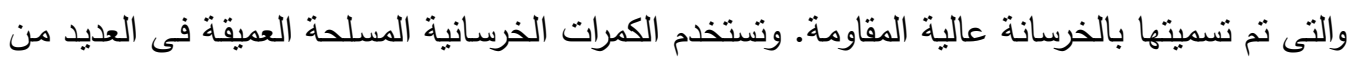

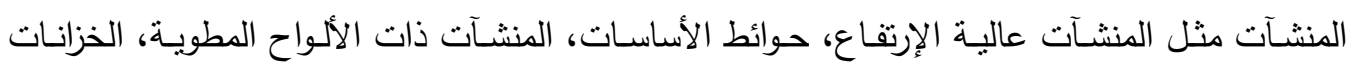
الرأسية ، وغيرها.

والغرض من هذه الدراسة الوقوف على سلوك القص للكمرات الخرسانية المسلحة العميقة عالية المقاومة ومدى تأثرها بكل من مقاومة الخرسانة والنسبة بين بحر القص إلى العمق الفعال ونسبة حديد التسليح الرئيسي ونسبة حديد التسليح الرأسي والأفقي وطول الرباط لحديد التسليح الرئيسي.

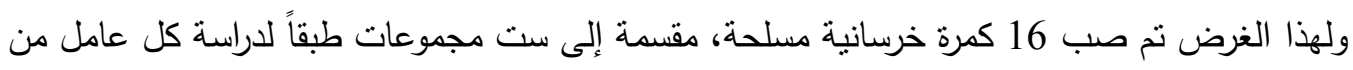
العوامل السابقة، وقد بينت الاختبارات ما يلى :

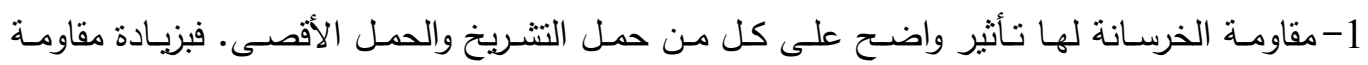

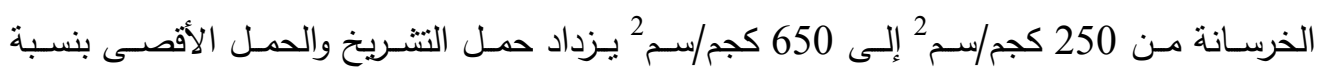

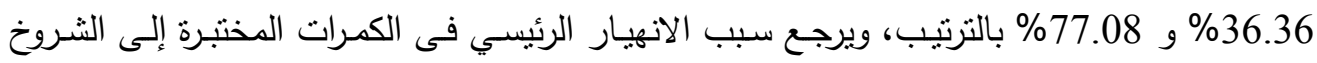
القطرية، حيث أن تفتت الخرسانة من العوامل الثانوية للخرسانة عالية المقاومة.

2-نسبة بحر القص إلى العمق لها تأثير واضح على حمل النتريخ، والحمل الأقصى للكمرات العميقة عالية المقاومة. 
3-زيادة حديد التسليح الرئيسي له نأثثر هام على حمل التشريخ والحمل الأقصى، ويزيد من حمل التشريخ والحمل الأقصى. 4-تزويد الكمرات العميقة بحديد رأسي لـه تأثثر صغير نسبياً على مقاومة الكمرات المختبرة، ولا يؤثر على تطور الثروخ المائلة. 5- الحديد الجانبي لـه تأثير قليل على حمل النتريخ، والحمل الأقصى للكمرات مقارنة بتفاصيل حديد

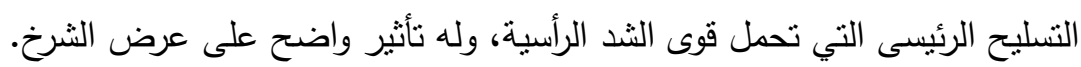

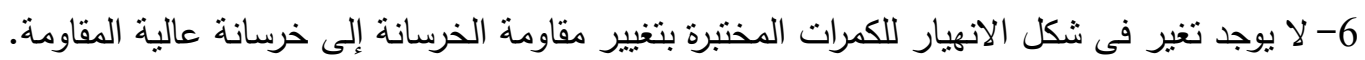
7- قيمـة أقصى ترخيم حـادث في الكمرات تقل بزيـادة مقاومـة الخرسـانة، وبزيـادة نسبة حديد التسليح الرئيسى. كذللك قيمـة أقصى ترخيم حادث فى الكمرات يزداد بزيادة نسبة بحر القص إلى العمق، وبزيادة نسبة التسليح الجذعى.

8-كلما زادت نسبة بحر القص إلى العمق، كلما كان منحنى الحمل-الترخيم أقل حدة. أى أن بزيادة نسبة بحر القص إلى العمق يكون المنحنى أكثر مرونة. وبزيادة نسبة بحر القص إلى العمق تقل قيمة الترخيم نتيجة لزيادة العزوم.

9-نسبة حديد التسليح الأفقي للكمرات العميقة لها تأثير واضح على التحكم فى الترخيم الحادث للكمرات، بينما نسبة النسليح الرأسي ليس لها تأثير يذكر فى التحكم فى الترخيم الحادث للكمرات.

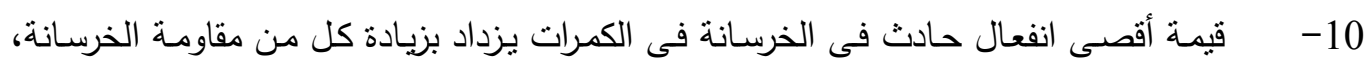

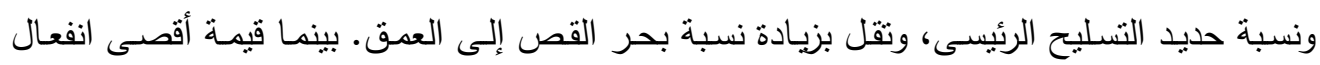

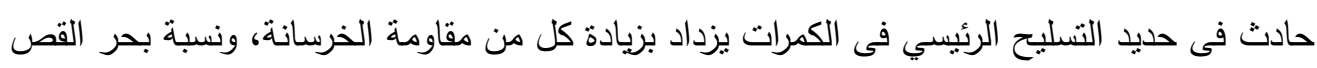
إلى العمق، ويقل بزيادة نسبة حديد التسليح الرئيسى.

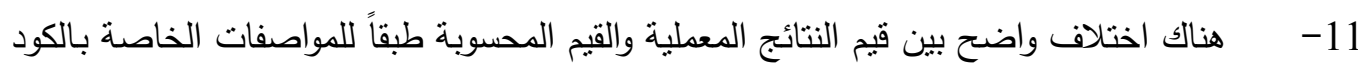
الأمريكي.

12- أمكن التوصل إلى معادلة تجريبية والتي عن طريقها يمكن التتبؤ بحساب قيم اجهادات القص عند بداية ظهور الثرخ الأول. 